\title{
Agency Costs, Corporate Governance and the Nature of Controlling Shareholders: Evidence From French Listed Firms
}

\author{
Dabboussi Moez \\ College of Humanities and Administrative Sciences \\ Department of Business Administration \\ Jouf University, Sakaka 72388, Saudi Arabia \\ Tel: 966-505-296-703 E-mail: dabboussi.moez@yahoo.fr
}

Received: September 7, 2018 Accepted: September 18, 2018 Published: September 26, 2018

doi:10.5296/ijafr.v8i3.13621

URL: https://doi.org/10.5296/ijafr.v8i3.13621

\begin{abstract}
This paper examines the impact of internal corporate governance on agency costs for French firms from 2000 to 2015. Our results reveal that shareholders themselves are not a homogenous group since they have no single common investment horizon. We found that managerial ownership is more effective in mitigating operational expenses. However, they take advantage of excessive spending on indirect benefits. We show that board of directors does not serve as a significant deterrent to excessive discretionary expenses. Finally, we found that dividend policy is a useful tool to reduce agency conflicts by reducing cash that is available for discretionary uses.
\end{abstract}

Keywords: Agency costs, Corporate governance, Controlling shareholders, French listed firms

JEL Classification: G30, G32, G35

\section{Introduction}

How to reduce agency problems that can arise between shareholders and managers? This is one of the big questions when corporate governance is addressed. Indeed, during the last decades, the issue has attracted the attention of many researchers and regulatory authorities. Its origin dates back to the debate initiated by Berle and Means (1932) that highlighted the problems inherent in the decision-ownership dichotomy. Since then, many researchers have become 
interested in the study of the agency problem, giving rise to several propositions about the firm's management structure. Indeed, Jensen and Meckeling (1976), founder of the agency theory, examined the conflicts of interest that arise between managers and shareholders when ownership and control are separated. To reduce this conflict, corporate governance theory provided answers as to the maximization of firm value and the elimination of any source of organizational inefficiency. According to Gugler et al. (2003 shows that a reliable and transparent governance system depends on its ability to align the interests of managers and shareholders and to maximize, as a result, shareholders wealth. Similarly, Swanson and Tayan (2011) and Damodaran (2015) defined corporate governance as a set of control mechanisms that the organization adopts to prevent or to dissuade managerial self-interest from engaging in activities disfavoring stakeholders' well-being.

In the literature, many internal corporate governance mechanisms are well documented. They mainly relate to the company's operational stakeholders who can control managerial decisions, Parrino et al. (2012). Therefore, the purpose of this study is to provide a clear vision of governance as well as its components. Specifically, we assess the effectiveness of these governance mechanisms through the application of the Corporate Governance Codes and Principles in the French context. The rest of the paper is organized as follows. Section 2 introduces the French corporate governance system and its institutional environment. Section 3 provides a literature review and hypothesis development. Section 4 presents the research design. Section 5 presents a discussion of the implication of the results. Concluding remarks and presents some directions for future research are presented in the last section.

\section{French Corporate Governance System and Its Institutional Environment}

Extending share ownership of French companies has favored establishing a debate about corporate power. Critics focused on the lack of a legal framework in order to push the CEO to be more transparent. Moreover, after a series of scandals (Enron, Andersen, Worldcom) that affected the world economy involving large companies, some economic fundamentals have been shaken. As a result, these scandals triggered a debate on the firm's organizational and operational outlook. In other words, a certain numbers of legal and accounting recommendations linking the different stakeholders were proposed by the AFEP (Note 1)-MEDEF (Note 2) Corporate Governance Code for Listed Companies. First, the Viénot1 report, published in July 1995 under the name of "The Board of Directors of listed companies", was primarily concerned with the Board of Directors of publicly listed companies, in view of clarifying their mission and making their business more effective. The report recommended the removal of cross mandates, the limitation of the number of directors in the Board of Directors, the use of independent directors and the creation of Board-operational committees.

Second, the Viénot 2 report, published in July 1999, took a broader perspective by promoting an approach giving companies the possibility of separating the positions of Chairman of the Board of Directors and the Chief Executive Officer. This report updates the notion of an independent Director with details on the notion of independence and strengthens the role of independent directors and the independence conditions for the exercise of their power. It also recommended the quick provision of financial information and communication for 
shareholders to be the role of general assemblies.

Third, the Bouton report (2002) has been developed as a result of the Enron crisis and aims at restoring investors' confidence. The report suggested undertaking a number of improvements to the Board of Directors (strengthening of independence of directors, a higher degree of formalization, quality of information, better assessment), committees (audit, remuneration and nomination committees), independence of Auditors and financial information.

With regard to the main legal texts adopted in France, the legal framework about governance in this country is subject to European directives issued by the European Parliament. This guideline was established in the Winter report, published in 2002, which aimed at modernizing the right companies and strengthening corporate governance standards. This report has established 10 priorities including the mandatory publication of an annual governance report of listed companies, a set of rules on shareholder rights, strengthening the influence of shareholders and transparency about Executive remuneration as well as a better coordination of corporate governance codes nation-wide. In the French context, three recent texts have attracted special attention. First, the law on the new economic Regulations (Act NRE) that complemented the Viénot report (1995) and the Button report (2002) and emphasizing the separation between management and control functions in order to strengthen the independence of Board members. Then, the financial security law (2003) has been designed as a French response to the trust crisis of financial markets caused by the several scandals (Enron, Vivendi...). The law aimed at strengthening the supervisory authorities' powers, with the creation of the financial markets authority (AMF) in an effort to achieve better protection for investors. Additionally, it aimed at strengthening the role and independence of Auditors as well as improving the quantity and quality of information provided to shareholders. Finally, the 2005 law on the modernization of the economy has strengthened the legal requirements about disclosing information on executive compensation, especially its components and its evaluation criteria.

\section{The Literature Review and Research Hypotheses}

Among an array of control mechanisms, Agency theory includes mechanisms that discipline managers and force them to act in shareholders' interest. Of these mechanisms, we distinguish ownership concentration, the presence of large shareholders, board structure and size, quality audit committees, debt effect, dividend policy and finally the Executive stock option payment.

\subsection{Impact of Ownership Concentration on Agency Costs}

Prior studies such as that of Jensen and Meckling, (1976), Demsetz (1983), Demsetz and Lehn, (1985), and Shleifer and Vishney (1986)) showed that when ownership is concentrated, management control would be effective. Indeed, blockholders agree to control managers and help to foster value-maximizing resource allocation. In addition, ownership concentration allows for rationalizing decision-making about dividend distribution. Examining a sample of 600 Canadian listed firms, Gadhoum (2000) found that a high ownership concentration of allows for establishing a meaningful relationship between shareholders and management by reducing conflicts of interest and information asymmetry. Similarly, La Porta et al.(2000b) and 
Shleifer and Vishny (1997) show ownership concentration lessens these distortions by reducing free cash flow for discretionary expenditures and by imposing, for example, greater financial discipline over managers. Although ownership concentration has been strongly considered as a mechanism of effective internal control to solve, at least in part, agency problems, we believe that, under certain conditions (such as high levels of capital concentration), it will lead to limited effectiveness when larges shareholders' interests diverge from those of the stakeholders. Therefore, we formulate the following hypothesis:

Hypothesis 1: ownership concentration has a negative impact on agency costs.

\subsection{The Presence of Controlling Shareholders}

Prior studies such as that of Parrino et al. (2012) show that large shareholders have an interest in inciting management to maximize shareholder value. However, Damodaran (2015) indicate that there is no magic bullet that will somehow turn bad managers into good managers or guarantee superior performance. In our study, it is important to determine the role of the different owners and to identify the factors behind their decisions. In what follows, we identify the disciplinary role of each shareholder in mitigating agency conflicts.

\subsubsection{Managerial Ownership and Agency Costs}

The literature identified two great forms of managerial discretions, which can lead to agency costs. First, the CEO often engages in economic activities that may improve their non-labor income, Jensen and Meckling (1976). This kind of behavior reduces firm wealth by increasing their costs. Second, managers may also increase their power and prestige through long-term investments that can increase firm size rather than benefits. In order to control this discretion, managerial ownership is considered as the most advantageous form to reduce agency costs. In fact, CEO becomes shareholder through incentive-based contracting which stipulates the right to profit from cash flow (incentive plans, acquisition of share capital, stock option plan.). Share ownership confers to owners the right to vote in the general assembly and the right to be elected to the administrative board. Consequently, the manager-shareholder position takes a dual function and is remunerated twice (wages and dividends), incurring the same shareholder risk. This justifies their motivation to preserve the company's interests, Fu and Wedge (2011). In addition, Maury (2004) support Jensen and Meckling (1976) by adding that the smaller the share held by the manager, the more this latter is able to adapt firm goods into particular advantages. The presence of managers in the ownership structure encourages them to act in favor of value maximization. It enables them to reduce control cost supported by shareholders who seek to maximize their wealth, in particular through dividends distribution. Therefore, we formulate the following hypothesis:

Hypothesis 2: managerial ownership negatively affects agency costs.

\subsubsection{Relationship Between Institutional Investors and Agency Costs}

Considered to be the major players in contemporary economy through their economic weight and their intervention, the influence of institutional investors (Note 3) on corporate governance and agency problems remains ambiguous. According to Agency theory, institutional 
shareholders with a significant capital share play a key role in alleviating agency problems. This is because they have the resources and the expertise to monitor management decisions at a lower cost, Henry (2004). According to Pound (1988), institutional investors can adopt the 'wall street walk' strategy by selling their stakes not to vote against the managers. Similarly, they may vote in favor of managers because of business relations with managers to identify conflicts of interest. However, institutional investors have an indirect influence on firm by ensuring the revocation of some Board Members. Also, they can vote against the proposals of the manager by highlighting their own measures or by expressing their displeasure by selling their shares; "voting with their feet", Swanson and Tayan (2011). Of their side, Doukas et al. (2000) showed that agency costs are not influenced by institutional ownership. They are passive towards control as they tend to diversify their portfolios. Therefore, we formulate the following hypothesis:

Hypothesis 3: institutional ownership negatively (positively) affects agency costs.

\subsubsection{The Relationship Between Family Ownership and Agency Costs}

The separation between the control and management functions in family businesses allows us to distinguish two types of conflicts. The first takes place when the family is the single majority shareholder. In this context, one speaks of a conflict of interest with minority shareholders. On the other hand, when families delegate an external manager, the second conflicts between managers and shareholders will arise, Morck et al. (1988). In the absence of a growth opportunity, family ownership plays an important role in reducing agency conflicts through the disciplinary role of managers, SanMartin-Reyna and Duran-Encalada (2012). This argument validates the hypothesis that ownership concentration in family businesses provides better supervision on managers. In other words, when they face low investment opportunities, they may be tempted to act opportunistically. In this case, a high level of family ownership is to compensate for the reduced level of investor protection. Family control over ownership structure of firms with growth opportunities could lead, to some extent, to squandering these opportunities, De Andres et al. (2005).

Hypothesis 4: There is a positive relationship between family ownership and agency costs

\subsubsection{The Relationship Between Foreign Ownership and Agency Costs}

An abundant literature on foreign investors suggests that they play a more important role than local investors in improving corporate governance. In effect, the basic idea is that firm's follow the corporate governance model of their countries of origin unless the firm is a subsidiary of a foreign company. These foreign administrators are shareholders who hold enough shares that enable them to absorb high control costs, therefore, they are motivated to check and correct management discretions, Grossman and Hart, (1988). However, Chen et al (2013) argue that foreign ownership know how to deal with opportunistic managers, mitigate agency conflicts in different international and cultural contexts and improve financial transparency. Subscribing to the resource dependence theory, Pfeffer (1972) pointed out that foreign sources present a mechanism of subcontracting which contributes to capital financing. In addition, foreign investors are more fundamental factors that help separate between owners and shareholders 
and also help the company to extend its control over managers' decision-making. Finally, choi and choi (2013) argue that the higher level of foreign ownership leads to a reduction of agency cost. Therefore, we formulate the following hypothesis:

Hypothesis 5: agency costs will be low when foreign shareholders are a majority.

\subsection{Board Characteristics and Capital Agency Costs}

The effect of board characteristics on resolving conflict of interests between managers and shareholders drew the attention of several researchers, Adam et al.(2010). To ensure that the Board works effectively, two features should be checked; its size and the presence of independent directors.

\subsubsection{The Role of Board Size in Mitigating Management Opportunism}

Jensen (1993) and Lehn et al. (2004) provides that Board of directors is responsible to represent and defend shareholders' interests, choose managers and watch them so that they do not act against other stakeholders. The literature also agrees on the importance of board size in resolving agency conflicts between managers and shareholders. For example, Beiner et al. (2004) found that among the consequences of a large number of administrators is the dilution of voting power, which is likely to reduce the firm's effectiveness. On the other hand, a small board may not be able to pursue its responsibilities in a satisfying way, which is detrimental to overall firm performance. According to Raheja (2003), there are conditions under which a small-sized board helps to mitigate agency conflicts between managers and shareholders. Sign and Davidson (2003) found that the larger the Board, the more available resources to monitor managers 'decisions. In their turn, Bhagat and Black (1999) found that size may have a dual effect (positive and negative) on agency costs. Others found that an optimum Board sizefor each firm rather than a uniform size for all firms is hypothesized, Hermalin and Weisbach (2003). Therefore, we propose the following hypothesis:

Hypothesis 6: board size has a positive (negative) impact on capital agency costs.

\subsubsection{Independence of Board Members}

Several studies suggest that independent directors are best placed to control managers and are more likely to work for the interest of shareholders, Agrawal and Knoeber (1996) and Henry (2004). In the same line of reasoning, Hermalin and Weisbash (1998) support the idea that boards usually include outside and internal directors with diverging motivations. Depending on the proportion of internal or external directors, the Board will be more or less independent. In addition, the number of Board members should be sufficient to make it work in an efficient and effective way to maximize long-term profitability for shareholders. However, other authors have found that a Board dominated by managers can lead to possible conflicts between internal directors and managers in an attempt to expropriate shareholders wealth. Raheja, (2005). In addition, Brealey et al (2014) argued that boards are sometimes portrayed as passive stooges who always champion the incumbent management.

Hypothesis 7: independent directors have a negative impact on agency conflicts. 


\subsection{The Relationship Between Audit Quality and Agency Costs}

Agency theory stipulates that an audit committee mitigate the inherent moral hazard problem between the principal and the agent, which gives rise to agency costs. In this regard, external auditors are supposed to strengthen governance structure while minimizing divergence of interests. Reaching these objectives highly depends on audit quality which depends in its turn on two factors; competence and independence. Several researchers found that audit quality strongly depends on membership to the biggest audit firms, as these latter have the reputation as well as the ability to absorb the blame for the loss of a mandate in case of accounts declassification, Klein and Leffler (1981). This type of Auditor plays an important role in monitoring financial information quality, and can therefore be considered an important element of the governance process, Alfraih (2016). Accordingly, high quality audit committees may limit opportunistic managers and mitigate risk while improving financial statements credibility and the work of the Board. Therefore, we propose the following hypothesis:

Hypothesis 8: A 'Big four' audit has a negative impact on agency costs

\subsection{The Role of Debt}

Debt provides managers with incentives to focus on maximizing cash flow and limit bad managers from wasting shareholder capital on unprofitable projects, Kayo and Kimura, (2011) and Parrino et al. (2012). In addition, debt plays a key role in motivating managers to be more effective by preserving and increasing their security and protects bondholders against over-investment risk, Onofrei et al. (2015) and Damodaran (2015). However, managers often dispose of a high proportion of their wealth, as a function of firm success. As a result, they tend to prefer less risk than shareholders who hold diversified portfolios. In the same line of thinking, the pecking order theory suggests a positive relationship between investment opportunities and leverage. This assumes that capital structure results from information asymmetry between managers and investors. This theory acknowledges that the manager is rational, but not necessarily opportunistic, Myers (1984). In a stage of firm maturity, debt no longer has the same disciplinary effect on managers, Kayo and Kimura, (2011). As a result, we assume that there is either a positive or a negative relationship between debt and firm value as stated in the following hypothesis:

Hypothesis 9: debt negatively (positively) correlates to agency costs.

\subsection{The Disciplinary Role of Dividends Distribution}

Financial theorists assumed that dividends distribution policies are disciplinary mechanisms of agency conflicts between shareholders and managers. In fact, Jensen (1986), Easterbrook (1984) and Quiry et al (2014) showed that an increase in the dividends payout ratio allows for resolving these conflicts by limiting free cash flow and, accordingly, managerial discretion. The latter will have to issue new shares in order to maintain level of investment. This type of capital increase requires managers to provide relevant information to shareholders, allowing them to reassess firm value. However, dividend can also generate conflicts between shareholders and creditors. In such a context, the interests of shareholders and managers are confused. They can make decisions about appropriating much of firm value at the expense of 
creditors. Indeed, shareholders could get wealth at the expense of bondholders by increasing firm risk, resulting in a decrease in bonds value. They can also adopt a suboptimal investment policy and pay dividends with uncommitted investment funds of projects with a positive net present value.

Hypothesis 10: dividends has a negative impact on capital agency costs

\subsection{Stock Options: An Incentive Mechanism for Managers}

Stock options give managers the right to buy their company's shares in the future at a fixed spot price. According to Fama (1980), stock options include fixing compensation on managerial performance. They encourage managers to maximize capital value to receive the option of the highest possible gain. Similarly, Jensen and Meckling (1976), Parrino et al.(2012) and Berk and Demarzo (2014) considered that the most effective way to align the interests of managers with those of shareholders is a well-designed compensation package that rewards executives when they do what shareholders want them to do and penalizes them when they do not. However, the introduction of this type of compensation seems a little difficult as it requires the implementation of procedures that measure managers' performance. If the interests of managers and shareholders converge, this promotes the emergence of a conflict with creditors. In this case, the company will focus on the highly risky projects in order to increase option value available to shareholders. In these circumstances, the manager may opt for riskier investments. According to Berk and Demarzo (2014) options are often attributed to the currency "at the money", meaning the spot price is equal to current currency rates. Therefore, managers are encouraged to be sensitive to bad news until the options are granted (spot price is down) and good news after the options are granted.

Hypothesis 11: Stock options compensation has a negative impact on agency conflicts.

\section{Research Design}

\subsection{Sample Data Collection}

To determine the impact of corporate governance on agency costs with the presence of controlling shareholders, we use a sample of French firms included in index CAC All Tradable over the period 2000-2015. We end up with 125 French firms for our empirical analysis. We refer to several data sources. First, our firm financial data come from worldscope database. Second, ownership structure, board characteristics, External Audit Committee and CEO stock option compensation data are derived from annual reports. Table 1 shows the classification of 125 firms by sectors.

Table 1. Classification of firms by sectors

\begin{tabular}{lll}
\hline Sectors & Number of firms & Percent \% \\
Technology & 28 & 22.4 \\
Consumer services & 22 & 17.6 \\
Industry & 21 & 16.8 \\
Consumer good & 15 & 12 \\
Healthcare & 10 & 8 \\
\hline
\end{tabular}




\begin{tabular}{lll}
\hline Community services & 8 & 6.4 \\
Software & 8 & 6,4 \\
Basic Materials & 5 & 4 \\
Telecommunication & 4 & 3,2 \\
Oil and gas & 4 & 3,2 \\
Total & 125 & $100 \%$ \\
\hline
\end{tabular}

\subsection{Variables Definition}

\subsubsection{The Dependent Variable: Agency Costs}

Previous literature has suggested many proxies for agency cost. In our study, we focus on direct agency costs (Note 4) which should result from the inefficient allocation of assets. We use four measures of agency costs such Asset Utilization ratio (AUR), Operating expenses ratio (Ope_Exp), Selling, general and administrative expenses (Adm_Exp) and Over-investment Risk (Over_Invest).

\section{- Asset Utilization ratio (AUR)}

We use the asset turnover ratio as an inverse proxy for agency costs. This ratio measures the effectiveness which the manager allocates assets to generate sales revenue, Truong and Heaney (2013). A high ratio means that managers take decisions that improve a firm's overall performance, create value for shareholders and shows that agency costs are low. Conversely, a low ratio shows that managers take bad investment decisions resulting in low income. Similarly, managers in this scenario consume excessive non-performing assets such as cars, fancy space office and resort facilities, (Ang et al. 2000; Fleming et al. 2005). Therefore, this ratio negatively relates to agency conflicts of equity (Note 5) between shareholders and managers.

\section{- Operating expenses ratio (Ope_Exp)}

Several studies have considered operating expenses ratio as a measures managers' effectiveness in controlling operational costs, including the excessive consumption of indirect benefits and other direct agency costs (Note 6). According to Singh and Davidson (2003), a relatively high ratio of operational expenses may indicate excessive spending on trading activities, which could be a signal that shareholder wealth is being expropriated by managers who tend to divert firm resources by raising operational expenses or investing in negative net present value projects, Shleifer and Vishny (1986). Therefore, this ratio should positively relate to agency costs.

\section{- Administrative expenses (Adm_Exp)}

Administrative costs represent a significant component of business operations, Hilton and Platt (2014) .This measure should reflect significantly managers 'discretionary behavior towards the company's resources allocation, as it can be a result of overspending on indirect benefits that include salaries, commissions collected by managers to facilitate transactions, travel costs, advertising and marketing costs, rent and other public services (Note 7). According to Anderson et al (2002), managers can retain unused resources to avoid personal consequences 
of retrenchment, such as loss of status, which contributes as consequence to excessive cost behavior. In addition, Eugene et Ehrhardt (2014) suggest that manager, rather than focusing on maximizing firm value, may spend too much time on external activities, such as serving other companies' boards of directors, or non-productive activities, such as golf and traveling. Therefore, the higher administrative expenses ratio should face agency costs between managers and shareholders.

\section{- Over-investment Risk (Over_Invest)}

The free cash flow theory, presented by Jensen (1986a), argues that managers have discretionary behaviors aver the firm investment decision with are detrimental to the shareholders wealth. Managers may become tempted to pursue their personal wealth or otherwise spend excess cash in ways not in the shareholders' best interests. Similarly, when free cash flow is positive, managers prefer to "stockpile" it in the form of marketable securities instead of returning the money to investors. They also may paying too much for the acquisition of another company, Eugene et Ehrhardt (2014). As a result, over-investment is when managers engage several investment projects that do not maximize shareholder wealth, creating conflicts of interests, reducing thus firm value and limiting consequently future growth opportunities, Myers (1977). In our study, over-investment risk is when free cash flow is positive as well as value firm measured by of tobin's $Q$ is below sector average.

\subsubsection{The Independent Variables}

Our research model includes a set of internal corporate governance variables representing ownership structure, the board characteristics, audit committee, managerial compensation and capital structure. Several control variables are also included. Consistent with prior studies (Holmstrom 1989, and Warren et al. 2014), we use the firm's tangible assets. Moreover, we include the natural logarithm of total assets as a proxy for firm, McConnell and Servaes, (1990). Finally, we use firm age, Agarwal and Gort (2002). Table 2 provides information on the measures of these variables that were adopted from previous related studies.

Table 2. Variables, definitions and sources

\begin{tabular}{|c|c|c|}
\hline Variable & Definition & Sources \\
\hline AUR & Total sales to total assets ratio & Worldscoop \\
\hline Ope_Exp & Discretionary operational expenses to total assets ratio & Worldscoop \\
\hline Adm_Exp & Administrative expenses to total sales ratio & Worldscoop \\
\hline Over_invest & $\begin{array}{l}\text { Dummy variable that takes } 1 \text { if Tobin's } Q \text { is below sector average and free cash flow is } \\
\text { positive, zero otherwise. }\end{array}$ & Worldscoop \\
\hline Bloc & Percentage of shares owned by the three largest shareholders & Annual report \\
\hline Man_Own & Dummy variable thattakes 1 if managerial ownership is more than $50 \%$, zero otherwise. & Annual report \\
\hline Inst_Own & Dummy variable that takes 1 if institutional ownership is more than $50 \%$, zero otherwis & Annual report \\
\hline Fam_Own & Dummy variable that takes 1 if Family ownership is more than $50 \%$, zero otherwise. & Annual report \\
\hline For_Own & Dummy variable that takes 1 if foreign ownership is more than $50 \%$, zero otherwise. & Annual report \\
\hline B_Size & The number of directors on the board & Annual report \\
\hline
\end{tabular}




\section{Mll Macrothink}

International Journal of Accounting and Financial Reporting

ISSN 2162-3082

2018, Vol. 8, No. 3

\begin{tabular}{|c|c|c|}
\hline B_Ind & $\begin{array}{l}\text { The number of independent outside directors to the total number of directors on the } \\
\text { board ratio }\end{array}$ & Annual report \\
\hline Audit & Dummy variable that takes 1 if the auditor is Big Four, zero otherwise. & Annual report \\
\hline Option & $\begin{array}{l}\text { Dummy variable that takes } 1 \text { if the CEO compensation structure includes stock options, } \\
\text { zero otherwise. }\end{array}$ & Annual report \\
\hline Debt & Total debt to total assets ratio & Worldscoop \\
\hline Div & $\begin{array}{l}\text { Common Dividends (Cash)/ (Net Income before Preferred Dividends - Preferred } \\
\text { Dividend Requirement) } * 100\end{array}$ & Worldscoop \\
\hline Tang & Tangible assets to total assets ratio & Worldscoop \\
\hline Size & The log of the firm's total asset. & Worldscoop \\
\hline Age & Age of the company since incorporation & Annual report \\
\hline
\end{tabular}

\subsection{Model Specification and Methodology}

In this study, our methodology consists in estimating three regressions, the difference between them being the measurement of the dependent variable. The model will be estimated by using the panel data method. Heteroscedasticity and autocorrelation are the two common problems that normally exist in a panel data analysis. Thus, the Breush-Pagan-Godfrey test, the Modified Wald test and the Wooldridge test are used to identify these problems respectively. Additionally, panel data technique, namely Prais-Winsten (PCSE) regression, is applied to account for these problems by using Stata Statistical Software: Release 13. The model to be tested is presented in the following form:

$$
\begin{aligned}
\text { Agency_cost }_{i, \mathrm{t}}= & \beta_{0}+\beta_{0} \text { Bloc }_{\mathrm{i}, \mathrm{t}}+\beta_{1} \text { Man_OWn }_{\mathrm{i}, \mathrm{t}}+\beta_{2} \text { Inst_Own }_{\mathrm{i}, \mathrm{t}}+\beta_{3} \text { Fam_Own }_{\mathrm{i}, \mathrm{t}}+\beta_{4} \text { For_Own }_{\mathrm{i}, \mathrm{t}} \\
& +\beta_{5} \mathrm{~B}_{-} \operatorname{Size}_{\mathrm{i}, \mathrm{t}}+\beta_{6} \mathrm{~B}_{-} \operatorname{Ind}_{\mathrm{i}, \mathrm{t}}+\beta_{7} \text { Audit }_{\mathrm{i}, \mathrm{t}}+\beta_{8} \text { Debt }_{\mathrm{i}, \mathrm{t}}+\beta_{9} \text { Div }_{\mathrm{i}, \mathrm{t}}+\beta_{10} \text { Option }_{\mathrm{i}, \mathrm{t}}+\beta_{11} \text { Tang }_{\mathrm{i}, \mathrm{t}} \\
& +\beta_{12} \text { Size }_{\mathrm{i}, \mathrm{t}}+\beta_{13} \text { Age }_{\mathrm{i}, \mathrm{t}}+\varepsilon_{\mathrm{i}, \mathrm{t}}
\end{aligned}
$$

- Where $\mathrm{i}$ indicate a particular company, $\mathrm{t}$ denotes the time in years, $\varepsilon \mathrm{i}, \mathrm{t}$ is a stochastic error term.

\section{-Descriptive Statistics of All Variables}

Table 3 present the descriptive statistics of corporate governance and agency costs variables used for the final sample of 2000 firm-year observations over the period 2000-2015. We find that the average firm agency cost is $0.9654,0.9668$ and 0.3432 , as measured by the asset allocation ratio, operational expenses and sales, general and administrative expenses. For the over-investment risk variable, it is observable at $42,35 \%$ during the study period. The number of board director's ranges from 3 to 24 . This makes of France the country with a high number of administrators. On average, firms in our sample have boards of directors consisting of nine directors (value close to the required maximum of 12 members). Also, board independence has an average of $34.70 \%$ with a minimum of $0 \%$ and a maximum of $94.11 \%$. Again, audit quality is around $75,20 \%$ of the sample, indicating that companies are audited by a Big 4 . The mean for the dividend payout variable is 25,76 . It shows that firms give high enough dividend payout to stockholders The mean of the total debt ratio is $18,09 \%$ which shows that the debt financing of all the companies in our sample is less than half of their assets. In addition, an examination of CEO compensation shows that, on average, $46.90 \%$ of manager's benefit from stock 
options. Among ownership structure variables, average ownership concentration of the three largest shareholders is $68,35 \%$ with a maximum of $99,99 \%$. The results of this variable shows that ownership structure in our sample is concentrated. In addition, majority managerial ownership, institutional ownership, family ownership and foreign ownership are observable respectively at $13.15 \%, 16.55 \%, 20.80 \%$ and $4.95 \%$.

Table 3. Descriptive statistics

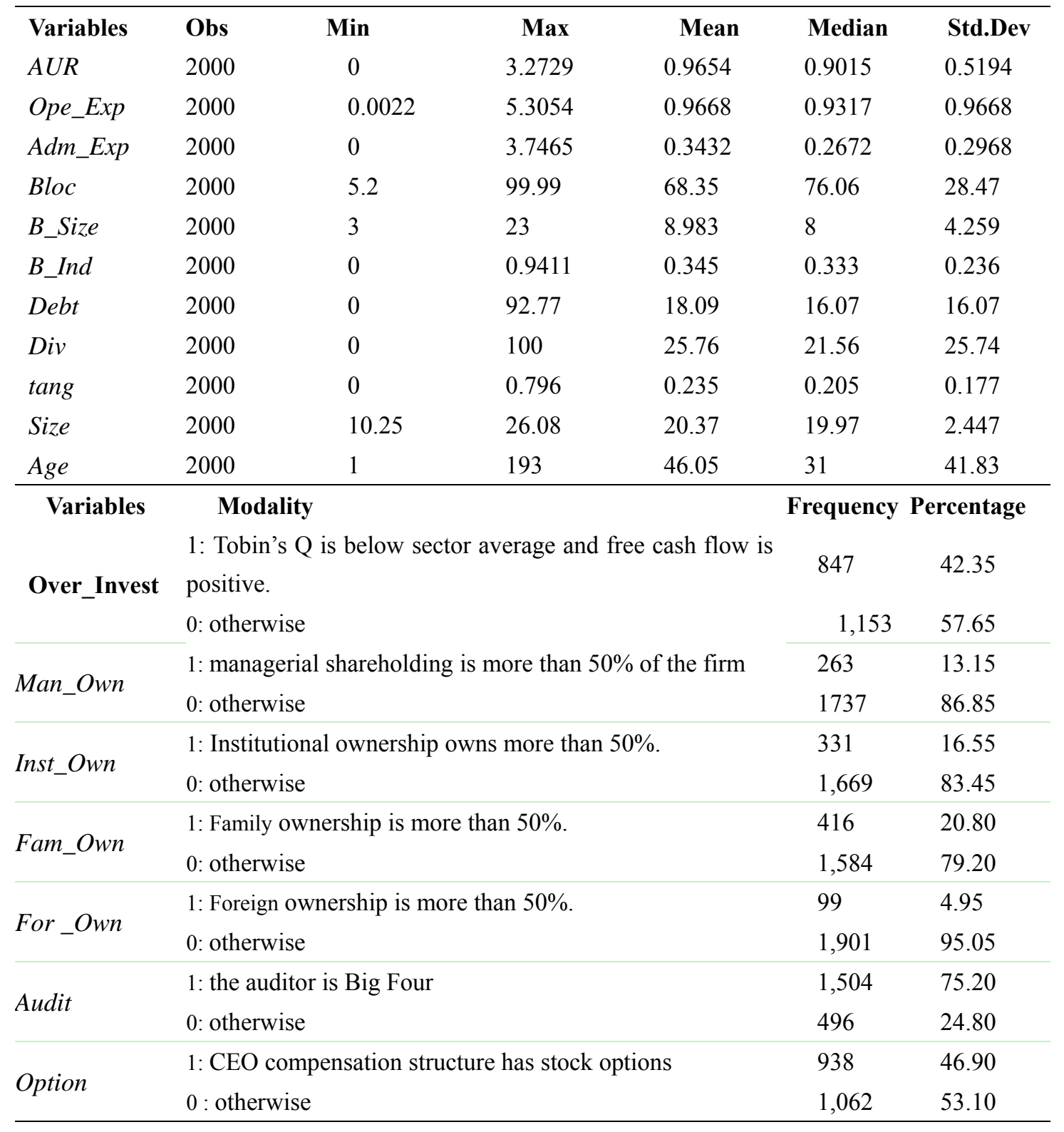

Notes: Obs. = Observation; Min. = Minimum; Max.= Maximum ; Std. Dev. = Standard Deviation;

Notes: Obs. $=$ Obesevations; Min. $=$ Minimum; Max. $=$ Maximum; Std. Dev. $=$ Standard Deviation;

- Correlation matrix

A possible strategy to detect multicollinearity is to use Spearman correlation analysis. Tables 4 


\section{MInstitute Macrothink}

International Journal of Accounting and Financial Reporting

ISSN 2162-3082

2018, Vol. 8, No. 3

indicate that the correlation coefficients between explanatory variables are generally below 0.80 , Gujarati (2003). The highest coefficient is 0.772 , representing the correlation between the board size and firm size. In addition, the results of the correlation analysis show that tangibility are not significantly correlated with the percentage of shares owned by the three largest shareholders. Moreover, there is no significant relationship between managerial owners and Institutional ownership, firm debt, dividend and the firm age respectively. Also, we find that there is no significant relationship between Institutional ownership and Big Four audit.

Table 4. Correlation matrix

\begin{tabular}{|c|c|c|c|c|c|c|c|c|c|c|c|c|c|c|}
\hline & 1 & 2 & 3 & 4 & 5 & 6 & 7 & 8 & 9 & 10 & 11 & 12 & 13 & 14 \\
\hline 1 & 1 & & & & & & & & & & & & & \\
\hline 2 & $0.267 * * *$ & 1 & & & & & & & & & & & & \\
\hline 3 & $-0.118 * * *$ & -0.033 & 1 & & & & & & & & & & & \\
\hline 4 & $0.194 * * *$ & $0.372 * * *$ & $-0.122 * * *$ & 1 & & & & & & & & & & \\
\hline 5 & $-0.182 * * *$ & $-0.088^{* * *}$ & $0.320 * * *$ & $-0.099 * * *$ & 1 & & & & & & & & & \\
\hline 6 & $-0.280^{* * *}$ & $-0.260 * * *$ & $0.228 * * *$ & $-0.240 * * *$ & $0.205^{* * *}$ & 1 & & & & & & & & \\
\hline 7 & $-0.224 * * *$ & $-0.179 * * *$ & $0.263^{* * *}$ & $-0.063 * * *$ & $0.201 * * *$ & $0.311 * * *$ & 1 & & & & & & & \\
\hline 8 & $-0.144^{* * *}$ & $-0.071 * * *$ & 0.012 & $-0.068 * * *$ & $0.067 * * *$ & $0.275^{* * *}$ & $0.184 * * *$ & 1 & & & & & & \\
\hline 9 & $0.119^{* * *}$ & 0.005 & $0.086^{* * *}$ & $-0.129 * * *$ & -0.031 & $0.146^{* * *}$ & -0.012 & $0.101^{* * *}$ & 1 & & & & & \\
\hline 10 & $-0.124 * * *$ & 0.018 & $0.064 * * *$ & $-0.048^{* *}$ & $0.074 * * *$ & $0.277 * * *$ & $0.094 * * *$ & $0.076^{* * *}$ & $0.070^{* * *}$ & 1 & & & & \\
\hline 11 & $-0.191 * * *$ & $-0.199 * * *$ & $0.225 * * *$ & $-0.158 * * *$ & $0.215^{* * *}$ & $0.431 * * *$ & $0.361 * * *$ & $0.233^{* * *} *$ & $-0.060 * * *$ & $0.068 * * *$ & 1 & & & \\
\hline 12 & 0.002 & $-0.078 * * *$ & $0.037 *$ & 0.019 & $0.096 * * *$ & $0.340^{* * *}$ & $0.132 * * *$ & $0.139 * * *$ & $0.349 * * *$ & $0.139^{* * *}$ & $-0.067 * * *$ & 1 & & \\
\hline 13 & $-0.239 * * *$ & $-0.243^{* * *}$ & $0.295^{* * *}$ & $-0.231 * * *$ & $0.205^{* * *}$ & $0.772 * * *$ & $0.418 * * *$ & $0.350^{* * *}$ & $0.209 * * *$ & $0.316^{* * *}$ & $0.510^{* * *}$ & $0.335 * * *$ & 1 & \\
\hline 14 & $-0.069 * * *$ & 0.014 & $0.141 * * *$ & $0.106^{* * * *}$ & $0.113^{* * *}$ & $0.395 * * *$ & $0.290 * * *$ & $0.120^{* * *}$ & $0.158 * * *$ & $0.205^{* * *}$ & $0.066^{* * *}$ & $0.342 * * *$ & 0.44 & 1 \\
\hline
\end{tabular}

This table shows the correlation matrixes of research variables. *, **, and *** indicate significance at the $10 \%, 5 \%$, and $1 \%$ levels respectively. 1 is the percentage of shares owned by the three largest shareholders. $\mathbf{2}$ is a dummy variable that takes 1 if managerial ownership is more than $50 \%$, zero otherwise. $\mathbf{3}$ is a dummy variable that takes 1 if Institutional ownership is more than 50\%, zero otherwise. 4 is a dummy variable that takes1 if Family ownership is more than $50 \%$, zero otherwise. $\mathbf{5}$ is a dummy variable that takes 1 if foreign ownership is more than $50 \%$, zero otherwise. 6 is the number of directors on the board. 7 present the ratio of the number of independent outside directors to the total number of directors on the board. 8 present a dummy variable that takes 1 if the auditor is Big Four, zero otherwise. 9 present total debt to total assets ratio. $\mathbf{1 0}$ is calculated as follows: Common Dividends (Cash)/ (Net Income before Preferred Dividends - Preferred Dividend Requirement) $* 100.11$ is a dummy variable that takes1 if CEO compensation structure has stock options, zero otherwise. 12 present the tangible assets to total assets ratio. 13 is the log of the firm's total assets. 14 is age of the company since incorporation. 


\section{Results and Discussion}

In order to assess correlation between agency costs and corporate governance, we will interpret the significance of each variable in the fourth regressions. Table 5 shows the results of our regressions. This finding indicates that ownership concentration seems to play an important role in mitigating administrative expenses by influencing managerial decisions, which is consistent with Jensen and Meckling, (1976). In addition, ownership concentration seems to affect investment decisions, precisely because of the relationship between ownership structure and agency problems, which is consistent with Pindado and de la Torre (2007). These authors found that ownership concentration reduces free cash flow available for discretionary expenses and this by imposing, for example, greater financial discipline.

Analyzing the identity of majority shareholders of our sample, we found that managerial ownership contribute to resolving agency conflicts, only at the level of reducing operational expenses. However, they are a source of conflict like administrative expenses. Indeed, when CEO have a majority shareholder, excessive spending on perks will be most important. This result corroborates that of Charreaux (1991) who found that beyond 50\%, management would work be at the expense of shareholders 'interests.

Our results also indicate that higher institutional ownership has no significant impact on the efficient allocation of assets, operational expenses as well as administrative expenditure, which is consistent with Doukas et al. (2000) and Singh and Davidson (2003). However, these majority shareholders play a key role in mitigating agency problems related to overinvestment risk because they can monitor management at lower costs as they have greater expertise and resources. They may also vote against proposals sponsored by the manager by putting forward their own measures or expressing their displeasure by selling their shares, "voting with their feet", Parrino et al. (2003) and Larcker and Tayan (2011).

The results also show that family ownership increases agency costs of equity, which is consistent with Morck and Yeung (2003) who argue that managers may act for the controlling family by using of pyramidal groups to separate ownership from control as well as the entrenchment of controlling families.

We see that the coefficients of foreign ownership are not significant in all four models, which is consistent with the idea that the governance-improving role of foreign ownership is relatively limited. This result is not consistent with Grossman and Hart, (1988) and Chen et al (2013) which found a negative relationship between the higher level of foreign ownership and agency cost of equity. In addition, we can notice that French privatized firms in our sample are audited by the Big 4. Therefore, foreign shareholders delegate their role of monitoring to reputable auditors that enhance firm transparency.

Contrary to the postulation of agency theory, this study argues that board size has a negative effect on the efficient allocation of assets. Knowing that the average Board size in our sample is around 8 or 9 members, a relatively high number, it seems that small boards are managed better in terms of coordinating the views of its members, thereby reducing agency conflicts, accelerating the decision-making process and lessening abusive behavior. This result confirms 
that of Jensen (1993), who predicted that a large board with7 and 8 members is less likely to work effectively and therefore easier to be controlled by the CEO.

In addition, Florackis and Ozkan (2004) found that the larger the Board, the higher will be agency costs. This is due to ineffective communication and bad decisions when increasing board size beyond an optimal required level, John and Senbet (1998). Although French law requires a detailed communication of companies about director independence criteria, it turns out that board independence is not an efficient mechanism to manage assets as well as discretionary administrative expenditures. Moreover, independent directors in France follow specific profiles: president of retirement, officials, academics... etc. Most of them accessed their positions through personal relationships or because they belong to the corporate network. Therefore, this puts some doubt on their independent profiles. This result confirms the conclusions of Brealey et al. (2014), who found that many board members may be long-standing friends of the CEO may be indebted to the CEO for help or advice. Therefore, the effectiveness of independent directors will be negligible. Similarly, we found that a big4 audit Committee helps mitigate over-investment risk, though it tends to reduce the effectiveness of allocating assets. This result confirms that of Piot (2010) who found that audit quality in the French context seems a valuable monitoring device that may improve debtholders protection, enhance reliability of accounting numbers when risk of transferring wealth at the expense of debtholders is significant. Although the use of debt as a financing tool can reduce agency costs, it can also be a source of conflicts.

Managers often dispose of a high proportion of their wealth, depending on firm success. Moreover, the results suggest that debt significantly and negatively relates to assets investment rates. This result indicates that creditors feel less the need to monitor executive's performance or to question their strategic decisions. As a result, they tend to rely more on shareholders to monitor and control the management team. However, the roles of creditors as well as dividends distribution are essential to control administrative expenses. In particular, bankers monitoring allows the company to invest cash flow in investments rather than leave managers to waste them in travel costs, advertising and marketing costs, salaries... etc.

Similarly, we confirm the free cash flow theory, a sound dividends distribution policy allows for reducing the misuse of resources, which explains its negative impact on over-investment risk. In other words, investors may ask for higher dividends or a stock repurchase not because these are valuable in themselves, but because they encourage a more careful, value-oriented investment policy.

We can add that forcing a firm to commit itself to pay dividends provides an alternative way of forcing managers to be disciplined when selecting investment projects reducing the cash that is available for discretionary uses. Opportunistic behavior of managers increases with stock options. Referring Berk and Demarzo (2014), the managers of French companies manipulate the "timing" of information disclosure in order to maximize stock options value, which intensifies agency costs associated with firm expenditures, Singh and Davidson (2003). 


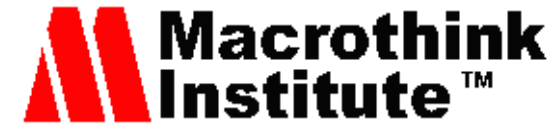

International Journal of Accounting and Financial Reporting ISSN 2162-3082

On the other hand, we found that stock options affect negatively overinvestment. This result indicates that this incentive plan may also be tempted to defer valuable investment projects if the projects would generate short-term earnings.

As for the control variables, we found several significant relationships in line with previous agency cost studies. First, we report that tangible assets reduce administrative expenses and overinvestment risk which is consistent with Ross et al.(2015) who argue that tangible assets like buildings and equipments cannot be converted to cash in normal business activity (they are, of course, used by the business to generate cash),reducing thus agency costs. We also found that the coefficient for firm size is negative and significantly related to return on assets. This result suggests that agency costs are higher for large firms.

Table 5. Regression results

\begin{tabular}{|c|c|c|c|c|}
\hline \multicolumn{5}{|c|}{ Prais-Winsten regression, Correlated panels corrected standard errors (PCSEs) } \\
\hline \multirow[t]{2}{*}{ Variables } & AUR & Ope_Exp & Adm_Exp & Over_invest \\
\hline & Coef & Coef & Coef & Coef \\
\hline Bloc & 0.00014 & 0.00014 & $-0.00049 * * *$ & $-0.00097 *$ \\
\hline Man_Own & 0.04564 & $-0.10189 * * *$ & $0.06476 * *$ & 0.07201 \\
\hline Inst_Own & -0.02302 & 0.03183 & -0.01198 & $-0.10744 * *$ \\
\hline Fam_Own & $-0.07237 * * *$ & $0.15048 * * *$ & -0.03442 & $0.11922 * * *$ \\
\hline For_Own & 0.00841 & 0.03826 & 0.01567 & 0.06096 \\
\hline B_Size & $-0.00962 * * *$ & 0.00304 & 0.00190 & $0.00714 *$ \\
\hline B_Ind & $-0.18481 * * *$ & -0.01579 & $0.05256^{*}$ & 0.09579 \\
\hline Audit & $-0.07488 * *$ & 0.03858 & -0.01244 & $-0.06965^{* *}$ \\
\hline Debt & $-0.00275^{* * *}$ & -0.00034 & $-0.00045^{*}$ & 0.00001 \\
\hline Div & 0.00043 & -0.00021 & $-0.00026 * *$ & $-0.00117 * *$ \\
\hline Option & -0.00510 & $0.11591 * *$ & 0.01083 & $-0.07447 * *$ \\
\hline Tang & 0.09229 & $0.20636^{* *}$ & $-0.17260 * * *$ & $-0.61197 * * *$ \\
\hline Size & $-0.07051 * * *$ & $-0.04553 * * *$ & $-0.04290 * * *$ & $0.03043 * * *$ \\
\hline Age & $0.03419 *$ & $-0.14811 * * *$ & 0.01362 & $0.05562 * *$ \\
\hline Constante & 2.49405 & 2.24995 & 1.22490 & -0.20000 \\
\hline R-squared & 0.6778 & 0.5320 & 0.3582 & 0.1566 \\
\hline Prob> chi2 & 0.0000 & 0.0000 & 0.0000 & 0.0000 \\
\hline Observations & 2000 & 2000 & 2000 & 2000 \\
\hline
\end{tabular}

Note: bloc is the percentage of shares owned by the three largest shareholders. Man_Own is a dummy variable that takes1 if managerial ownership is more than $50 \%$, zero otherwise. Inst_Own is a dummy variable that takes 1 if Institutional ownership is more than $50 \%$, zero otherwise. Fam_Own is a dummy variable that takes1 if Family ownership is more than 50\%, zero otherwise. For_Own is a dummy variable that takes1 if foreign ownership is more than $50 \%$, zero otherwise. B_Size is the number of directors on the board. B_Ind is the ratio of the number of independent outside directors to the total number of directors on the board. Audit is a dummy variable that takes 1 if the auditor is Big Four, zero otherwise. Debt is total debt to total assets ratio. Div is calculated as follows: Common Dividends (Cash)/ (Net Income before 
Preferred Dividends - Preferred Dividend Requirement) *100. Option is a dummy variable that takes 1 if CEO compensation structure has stock options, zero otherwise. Tang is tangible assets to total assets ratio. Size is the log of the firm's total assets. Age is age of the company since incorporation. $* * *$ Indicate significance at the $1 \%$ level. $* *$ Indicate significance at the $5 \%$ level. * Indicate significance at the $10 \%$ level.

\section{Concluding Remarks and Future Research}

Various corporate governance mechanisms are proposed to solve problems resulting from conflicts of interest between management's personal interests and the goal of maximizing shareholder wealth. However, the effectiveness of these disciplinary mechanisms is also being questioned in the presence of opportunistic managerial behavior. Consequently, it is important to clarify theoretical and empirical findings regarding the role of governance mechanisms as a means of reducing principle-agent conflicts. Additionally, this study was an opportunity to verify if French companies have adopted, in a disputable manner, the very highest standards of corporate governance. In other words, we attempt to validate if the corporate governance principles and recommendations was effective for resolving agency problems.

The French corporate governance system and institutional environment formed the starting point of our analysis. Then, we had reviewed the main previous and recent empirical literature, which studied the impact of the main internal governance mechanisms on agency costs. Examining a sample of 125 companies, our main conclusion is that the identity of controlling shareholders plays an important role in managing agency problems. They have an interest in providing management incentives to maximize shareholder value. However, only majority shareholders, who have a significant shore of the company, have enough money at stake and enough power to be motivated to actively monitor managers and attempt to influence their decisions. In contrast, we found that these shareholders themselves are not homogenous because they do not have a single common investment horizon. Investors with a long-term investment horizon could tolerate significant fluctuations in quarterly results and share price when they believe that top-executive decisions are made to achieve a higher profitability level. On the other hand, investors with a short-term investment horizon prefer short-term profit maximization. In the same line of thinking, the results indicate that ownership concentration is a disciplinary mechanism to control managerial opportunism.

Examining their corporate governance practices and reality, French firms are well positioned with regard to international standards. Quality of their financial information has been enriched in a satisfying manner. Similarly, this country does not comply with the highest governance standards when it comes to the board of directors. Some progress is to be made to level with Europe and North America. For the latter, the standards are that the manager in limited to2 mandates in external companies. In addition, most of independent directors in France accessed their positions through personal relationships or because they belong to the corporate network. Therefore, this questions their independent profiles. In fact, the latter has no incentives to report on capital agency costs. Other internal governance mechanisms have proved their inefficiency in controlling managerial opportunism in terms of in reducing overinvestment risk, like audit quality, dividend policy and stock options. Future research in other emerging 


\section{MInstitute ${ }^{m}$ Macrothink}

International Journal of Accounting and Financial Reporting

ISSN 2162-3082

2018, Vol. 8, No. 3

contexts would help to consolidate and refine our conclusions. In Particular, a comparative research based on corporate governance models is needed.

The study has produced some interesting results and one avenue for future research by studying opportunities for interaction (complementarities or substitutability) between governance mechanisms and disciplinary mechanisms in explaining agency plans. We can also use the "Corporate Governance Score" by identifying the level of governance (low, medium, and high) and which gives us an idea of the internal governance mechanisms used by the company, and more specifically of their application.

\section{References}

Agarwal, R., \& Gort, M. (2002). Firm and Product Life Cycles and Firm Survival. American Economic Review, 92(2), 184-190.

Agrawal, A., \& Knoeber, C. (1996). Firm performance and mechanisms to control agency problems between managers and shareholders. The Journal of Financial and Quantitative Analysis, 31, 377-397.

Alfraih, M. M. (2016). The role of audit quality in firm valuation: Evidence from an emerging capital market with a joint audit requirement. International Journal of Law and Management, 58(5), 575-598.

Ang, J. S., Cole, R. A., \& Lin, J. W. (2000). Agency Costs and OwnershipStructure. Journal of Finance, 55, 81-106.

Beiner, S., Drobetz, W., Schmid, M. M., \& Zimmermann, H. (2004). Is board size an independent corporate governance mechanism?. Kyklos, 57, 327-356.

Berk, J., \& Demarzo, P. (2014). Corporate finance (3rd ed.), pp. 962-964. Jarrad Harford.

Berle, A., \& Means, G. (1932). The Modern Corporation and Private Property. MacMillan, New York.

Bhagat, S., \& Black, B. (1999). The uncertain relationship between board composition and firm performance. Business Lawyer, 54, 921-963.

Brealey, R., Myers, S., \& Allen, F. (2014). Principles of Corporate Finance (11th ed.). The McGraw - Hill Companies.

Charreaux, G. (1991, May). Ownership structures, agency relationship and financial performance Ownership structures, agency relationship and financial performance. Economic Review Flight, 42(3), 521-552.

Chen, Z., Du, J., Li, D., \& Ouyang, R. (2013). Does foreign institutional ownership increase return volatility? Evidence from China. Journal of Banking and Finance, 37(2), 660-669.

Choi, Y., \& Choi, J. (2013). The Foreign Ownership and the Debt Maturity Structure. International Journal of Digital Content Technology and its Applications (JDCTA), 7(13).

Damodaran. (2015). Applied Corporate Finance (4th ed.). John Wiley \& Sons. 


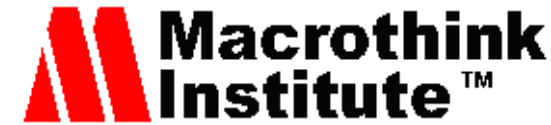

International Journal of Accounting and Financial Reporting

ISSN 2162-3082

2018, Vol. 8, No. 3

De Andres, P., Azofra, V., \& Lopez, F. (2005). Corporate boards in OECD countries: Size composition, functioning and effectiveness. Corporate Governance: An International Review, 13(2), 197-210.

Demsetz, H. (1983). The structure of ownership and the theory of the firm. Journal of Law and Economics, 26, 375-390.

Demsetz, H., \& Lehn, K. (1985). The Structure of Corporate Ownership: Causes and Consequences. Journal of Political Economy, 93(6), 1155-1177.

Doukas, J., Kim, C., \& Pantzalis, C. (2000). Security analysts, agency costs, and company characteristics. Financial Analysts Journal, 56(6), 54-63.

Easterbrook, F. (1984). Two agency cost explanations of dividends. The American Economic Review, 74, 650-659.

Fama, E. F. (1980, April). Agency problems and the theory of the firm. Journal of Political Economy, 88, 288-307.

Fama, E. F., \& Jensen, M. C. (1983, June). Separation of ownership and control. Journal of Law and Economics, 26, 301-326.

Florackis, C., \& Ozkan, A. (2004). Agency Costs and Corporate Governance Mechanisms: Evidence for UK Firms. Working Paper, University of York, UK.

Fu, R., \& Wedge, L. (2011). Managerial ownership and the disposition effect. Journal of Banking and Finance, 35(2011), 2407-2417.

Gadhoum, Y. (2000). Ownership Concentration, Dividend Policy, and Expropriation of Minority Shareholders. Working Paper.

Grossman, S. J., \& Hart, O. (1988). One share - one vote and the market for corporate control. Journal of Financial Economics, 20(1), 175-202.

Gujarati, D. N. (2003). Basic Econometrics (4th ed.). New York: McGraw Hill.

Henry, D. (2004). Corporate governance and ownership structure of target companies and the outcome of takeover bids. Pacific-Basin Finance Journal, 12, 419-444.

Hermalin, B. E., \& Weisbach, M. S. (1998). The Determinants of Board Composition. The Rand Journal of Economics, 19(4), 589-606.

Hermalin, B. E., \& Weisbach, M. S. (2003). Board of Directors as an Endogenously Determined Institution: Survey of the Economic Literature. NBER Working Paper 8161.

Hilton, R., \& Platt, D. (2014). Managerial Accounting: Creating Value in a Dynamic Business Environment (10th ed.). McGraw-Hill Education, New York.

Holmstrom, B. (1989). Agency costs and innovation. Journal of Economic Behavior and Organization, 12(3), 305-327. 


\section{Mll Macrothink}

International Journal of Accounting and Financial Reporting

ISSN 2162-3082 2018, Vol. 8, No. 3

Jensen, M. C. (1986). Agency Costs of Free Cash Flow, Corporate Finance, and Takeovers. American Economic Review, (2), 323-329.

Jensen, M. C. (1993). The modern industrial revolution, exit, and the failure of internal control systems. The Journal of Finance, 48(3), 831-880.

Jensen, M. C., \& Meckling, W. H. (1976). Theory of the Firm: Managerial Behavior, Agency Costs, and Ownership Structure. Journal of Financial Economics, 3, 305-360.

John, K., \& Senbet, L. W. (1998). Corporate governance and board effectiveness. Journal of Banking \& Finance, 22, 371-403.

Kayo, E. K., \& Kimura, H. (2011). Hierarchical determinants of capital structure. Journal of Banking and Finance, 35(2), 358-37.

Klein, B., \& Leffler, K. B. (1981). The role of market forces in assuring contractual performance. Journal of Political Economy, 89, 615-641.

LaPorta, R., Lopez, F., Shleifer, A., \& Vishny, R. W. (2000b). Agency problems and dividend policies around the world. Journal of Finance, 55, 1-33.

Larcker, D., \& Tayan, B. (2011). Corporate Governance Matters: A Closer Look at Organizational Choices and Their Consequences. Pearson Education, Inc. Publishing as FT Press Upper Saddle River, New Jersey.

Lehn, K., Sukesh, P., \& Zhao, M. (2004). Determinants of the size and structure of corporate board. Working Paper, Katz Graduate School of Business.

Maury, B. (2004). Essays on the Costs and Benefits of Large Shareholders in Corporate Governance. Publications of the Swedish School of Economics and Business Administration No 127.

McConnell, J., \& Servaes, H. (1990). Additional evidence on equity ownership and corporate value. Journal of Financial Economics, 27, 595-612.

Morck, R., \& Yeung, B. (2003). Agency Problems in Large Family Business Groups. Entrepreneurship Theorym \& Practice, 27(4), 367.

Morck, R., Shleifer, A., \& Vishny, R. (1988). Management ownership and market valuation: An empirical analysis. Journal of Financial Economics, 20, 293-315.

Myers, S. (1977). Determinants of corporate borrowing. Journal of Financial Economics, 5, 147-75.

Myers, S. C., \& Majluf, N. S. (1984). Corporate financing and investment decisions when firms have information that investors do not have. Journal of Financial Economics, 13(2), 187-221.

Onofrei, M., Tudose, M. B., Durdureanu, C., \& Anton, S. G. (2015). Determinant factors of firm leverage: An empirical analysis at Iasi county level. Procedia Economics and Finance, 460-466. 


\section{Macrothink}

International Journal of Accounting and Financial Reporting

ISSN 2162-3082

2018, Vol. 8, No. 3

Parrino, R., Kidwell, D., \& Bates, T. (2012). Fundamentals of Corporate Finance (2nd ed.). John Wiley \& Sons, Inc.

Pfeffer, J. (1972). Size and composition of corporate boards of directors: The organization and its environment. Administrative Science Quarterly, 17, 218-228.

Pindado, J., \& Torre, C. (2007, June). Effect of Ownership Structure on Underinvestment and Overinvestment: Empirical Evidence from Spain. Accounting and Finance.

Piot, C. (2010). Agency costs and audit quality: evidence from France. European Accounting Review, 10(3).

Pound, J. (1988). Proxy contests and the efficiency of shareholder oversight. Journal of Financial Economics, (20), 237-265.

Quiry, P., Dallocchio, M., Le Fur, Y., \& Salvi, A. (2014). Corporate finance: theory and practice. Pierre Vernimmen (4th ed.). John Wiley and Sons, Ltd.

Raheja, C. (2003). The Interaction of Insiders and Outsiders in Monitoring: A Theory of Corporate Boards. Working Paper, Vanderbilt University.

Raheja, C. (2005). Determinants of board size and composition: A theory of corporate boards. Journal of Financial and Quantitative Analysis, 40(2), 283-306.

Ross, S., Westerfield, R., \& Jordan, B. (2015). Fundamentals of Corporate Finance (10th ed.). McGraw-Hill/Irwin Companies.

San Martin-Reyna, J. M., \& Duran-Encalada, A. (2012). The relationship among family business, corporate governance and firm performance: Evidence from the Mexican stock exchange. Journal of Family Business Strategy, 106-117.

Shleifer, A., \& Vishny, R. W. (1986). Large shareholders and corporate control. Journal of Political Economy, 95, 461-488.

Shleifer, A., \& Vishny, R. W. (1997). A survey of corporate governance. Journal of Finance, $52,737-783$.

Singh, M., \& Davidson III, W. (2003). Agency costs, ownership structure and corporate governance mechanisms. J. Bank. Finance, 27, 793-816.

Swanson, D., \& Tayan, B. (2011). Corporate Governance Matters: A Closer Look at Organizational Choices and Their Consequences. Pearson Education, Inc. Publishing you FT Press Upper Saddle River, New Jersey.

Truong, T., \& Heaney, R. (2013). The determinants of equity agency conflicts between managers and shareholders: Evidence from Australia. Journal of Multinational Financial Management, 23, 314-326.

Warren, C., Reeve, J., \& Duchac, J. (2014). Financial and Managerial Accounting. Southwestern, Cengage Learning. 


\section{Macrothink \\ International Journal of Accounting and Financial Reporting \\ ISSN 2162-3082 \\ 2018, Vol. 8, No. 3}

\section{Notes}

Note 1. French Association of Private Sector Companies. http://www.afep.com/

Note 2. The Movement of French Enterprises. http://www.medef.com/en/

Note 3. We have considered institutional investors, banks, investment companies, insurance companies and social security funds.

Note 4. The term "direct agency" costs come in two forms. The frst type is a corporate expense that benefits management but costs the stockholders. The second type is an expense that arises from the need to monitor management actions, Ross et al (2015).

Note 5. The asset turnover ratio can also capture (to some extent) the agency cost of debt. For example, the sales ratio provides a good signal to the lender about how effectively the borrower will employ his assets and, therefore, affect the cost of capital.

Note 6. Operational expenses exclude the costs of goods sold, interest costs, leasing, hiring costs, depreciation and bad debts.

Note 7. Administration fees and other costs are non-production costs. These include post, Telegraph and phone costs, transport costs and travel cost, salaries, wages and other benefits, the depreciation charges. Sales and distribution costs are also the non-production costs, but they directly relate to generation of revenue from saleable products.

\section{Copyright Disclaimer}

Copyright for this article is retained by the author(s), with first publication rights granted to the journal.

This is an open-access article distributed under the terms and conditions of the Creative Commons Attribution license (http://creativecommons.org/licenses/by/4.0/) 